\title{
Late Scythian-Anisian ostracods (Crustacea) from the Meged-2 borehole, central Israel
}

\author{
AVRAHAM HONIGSTEIN ${ }^{1, *}$ \& SYLVIE CRASQUIN ${ }^{2}$ \\ ${ }^{1}$ Ministry of National Infrastructures Oil and Gas section, 234 Jaffa Rd, P.O.B. 36148, Jerusalem 91360, Israel \\ ${ }^{2}$ CNRS, UMR 7207 CR2P, UPMC, Laboratoire de Micropaléontologie T.46-56, E.5, case 104, 75252 Paris, Cedex 05, France \\ ${ }^{*}$ Corresponding author (e-mail: ahonigstein@mni.gov.il)
}

\begin{abstract}
Cutting samples from the Zafir Formation in the Meged-2 well (5013-5200 m), central Israel, were examined for ostracods. Seventeen species, belonging to eleven genera, could be distinguished. Five of them are described here as new species: Bairdia megedensis nov. sp., Bairdia bariudini nov. sp., Renngartenella ragilis nov. sp., Renngartenella perii nov. sp. and Patellacythere ephraimi nov. sp. Six species of the genera Renngartenella, Mostlerella and Kerocythere may also represent new taxa, but were left in open nomenclature, due to their rare occurrence in the samples. Only one species has been reported from other localities. Punctate forms of the genus Bairdia and Paracypris sp. are the most common species in the samples. The ostracods indicate a normal open-marine environment of deposition. The ostracod assemblages point to a Late Scythian-Anisian age, confirmed by foraminiferal and palynological data, but this age assignment remains disputed until the new taxa described here have been independently dated. J. Micropalaeontol. 30(1): 17-31, May 2011.
\end{abstract}

KEYWORDS: Ostracods, new species, central Israel, Meged-2 well, Scythian, Anisian

\section{INTRODUCTION}

The Late Permian mass extinction was the greatest during Phanerozoic times. The Permian-Triassic boundary is the most important turnover in the evolution of ostracods. A change from Palaeozoic to 'Meso-Cenozoic' forms is clearly recorded at this period. But, in detail this transformation was not abrupt (Crasquin-Soleau et al., 2007). The first Mesozoic forms appeared in the Wuchiapingian (Fig. 1). The main extinction event occurred during the latest Changhsingian, followed by a survival interval with mixed fauna (Palaeozoic and Mesozoic taxa) from the latest Changhsingian to the end of the Griesbachian. After that, a poverty interval is observed during the Dienerian-Smithian. During the Spathian a recoverydispersal stage is recorded. Late Palaeozoic age forms are still recognized in the Lower Anisian. So, a long ( $9 \mathrm{Ma}$ ) transitional interval in the ostracod turnover can be defined from the Wuchiapingian up to the Lower Anisian. During Early Anisian time, the great radiation of Mesozoic forms began. However, few data are recorded on Early Triassic and Anisian age ostracods. A compilation of the available literature is given in Crasquin-Soleau et al. (2007).

Middle-Late Triassic age ostracods were reported from Israel by Gerry (1967), Gerry \& Oertli (1967), Sohn (1968) and Hirsch \& Gerry (1974) and from Jordan by Basha (1982). The biostratigraphical zonation, based on foraminifera and ostracods from many unpublished borehole sections, was established by Gerry \& Derin (1981).

The Meged-2 well (Fig. 2) was the first well drilled in the Meged structure near Rosh Ha'ayin in central Israel at coordinates E $34^{\circ} 58^{\prime} 45^{\prime \prime}$, N 32 $08^{\prime} 22^{\prime \prime}$ (E 686751, N 3557668 - UTM zone 36, WGS84 datum). The Meged structure is an inverse Early Mesozoic fault structure, folded during the Syrian Arc folding events in the Late Cretaceous-Oligocene. It is considered a southwestern extension of the Syrian Palmyra Rift, called here the Galil Rift.

The Meged-2 well was drilled during 1994 and reached a total depth (TD) of $5200 \mathrm{~m}$. The Triassic occurs in this borehole from
$3430 \mathrm{~m}$ depth to the base of the well. No cores were taken in this well; cuttings were sampled at $3 \mathrm{~m}$ intervals. The original test of the well failed due to technical reasons; in a later test, oil was detected in non-commercial quantities because of the low porosity and permeability of the Triassic reservoir rocks. Three additional Meged wells (M-3-M-5), with TDs of $4900 \mathrm{~m}$ maximum, were drilled over recent years in this structure but did not reach the strata examined here. Commercial oil production will start towards the end of 2011 from the Meged-5 well from Carnian sediments.

The deepest section in the Meged-2 well (5013-5200 m) was examined in this study for its ostracod content. Permian taxa were assumed to occur in these samples (see also Benjamini, 1995), but this assumption could not be verified.

\section{GEOLOGICAL SETTING}

Most knowledge on the Triassic of Israel is summarized in Benjamini et al. (2005). The Triassic stratigraphy in Israel is based on palaeontological and lithological data from outcrops and numerous boreholes in southern Israel (Druckman, 1974), but the facies types there are very different from the more northern area. Triassic sediments occur in northern and central Israel only in a few borehole sections, but reach thicknesses of several kilometres. Few articles have been published on the biostratigraphy and correlation of the northern and central Israel area with the southern part of the country (Korngreen \& Benjamini, 2007; 2011).

Late Anisian-Scythian age faunal and floral elements were observed in Israel within the Raaf and Zafir formations. In southern Israel, sediments of the Zafir Formation are predominantly clastic, although frequently in marine facies. They consist of calcareous and pyritic shales, alternating with sandy, glauconitic or dolomitic limestones. In northern Israel, the lower part of the Triassic section appears to be in a rather uniform micrite and pelmicrite lithology (Benjamini et al., 2005). Korngreen \& Benjamini (2011: table 2) attribute these sediments in the Meged-2 section tentatively to the Anisian Gevanim Formation. 


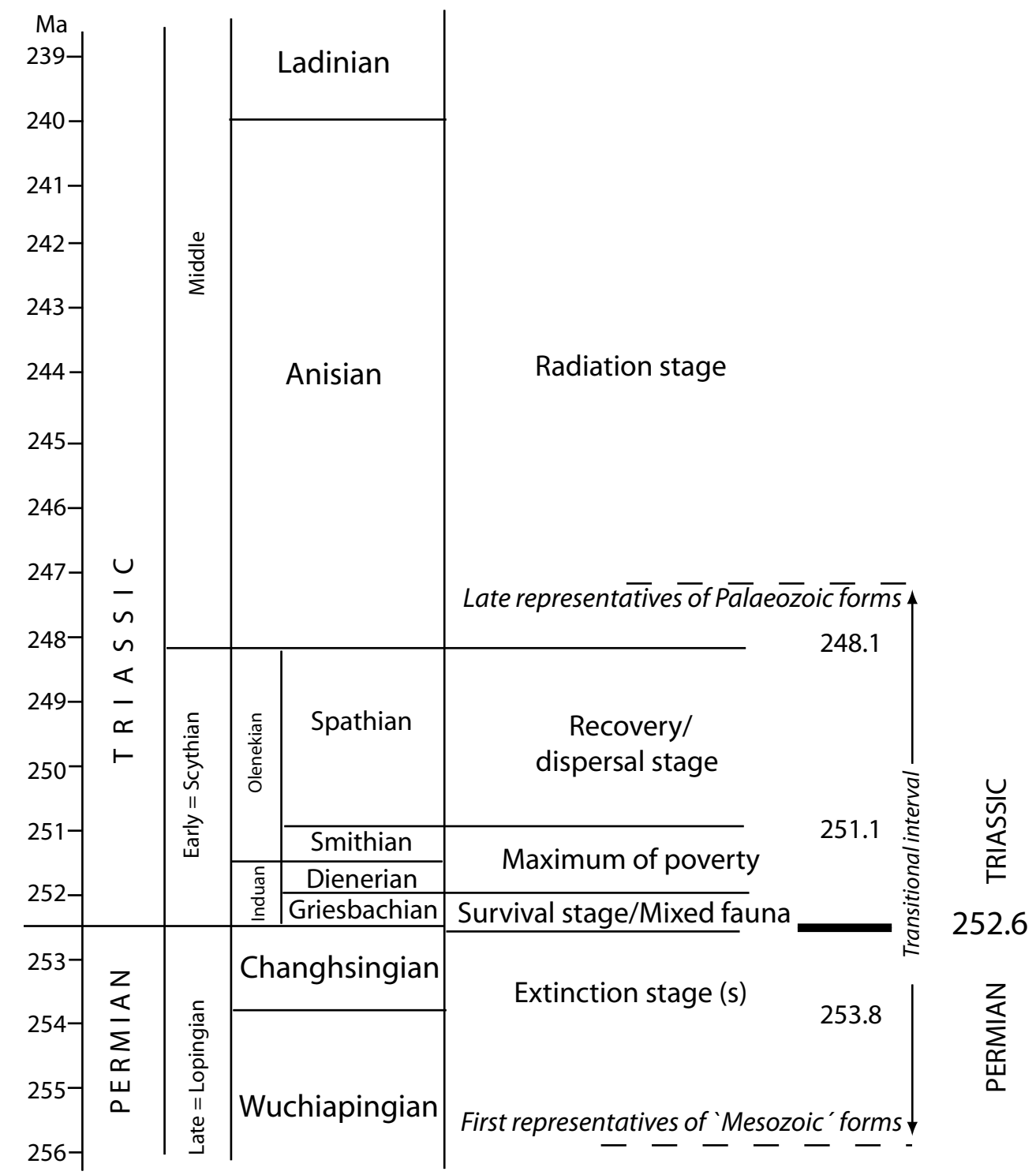

Fig. 1. Evolution scheme of ostracods through the Permian-Triassic boundary (modified after Crasquin-Soleau et al., 2007).

However, direct correlation of formation names, based on lithology or geophysical markers, is sometimes questionable and biostratigraphical data tend to show the irrelevance of common nomenclature. Therefore, in the present paper we follow the formation names cited in the well report.

In the well completion report of the Meged-2 well (Givot Olam, 1995), the whole section below $5000 \mathrm{~m}$ was defined as the Zafir Formation. However, the uppermost interval (5000$5013 \mathrm{~m}$ ) should be referred to the Raaf Formation (Fig. 3) or its equivalent, based on the wireline markers, the harder lithology with relatively thick limestone beds and the foraminiferal assemblage in this part (Benjamini, 1995).

The section between $5013 \mathrm{~m}$ and the TD, here defined as the Zafir Formation, was described by Givot Olam (1995) as follows:

- 5013-5035 m: Shale (60\%) with limestone interbeds $(40 \%)$.
Shale: grey to dark grey, soft, tight, illitic-kaolinitic, silty with quartz grains, glauconite and pyrite.

Limestone: white to grey, firm to moderately hard, tight, partly dolomitized, microcrystalline with fossils, stylolites, pellets and intraclasts.

- 5035-5036 m: Limestone (100\%).

Limestone: as above.

- 5036-5107 m: Shale $(65-75 \%)$ with argillaceous limestone interbeds $(25-35 \%)$.

Shale: grey to dark grey, soft to firm, tight, illitic-kaolinitic, silty with quartz grains, glauconite and pyrite. Occasionally shale, brownish and red, soft with volcanic matter.

Limestone: as above, but more argillaceous.

- 5107-5200 m: Silty shale $(60 \%)$ with shale interbeds $(40 \%)$, trace limestone.

Silty shale: brownish, occasionally red, soft with volcanic matter and sandy quartz grains.

Shale: as above. 


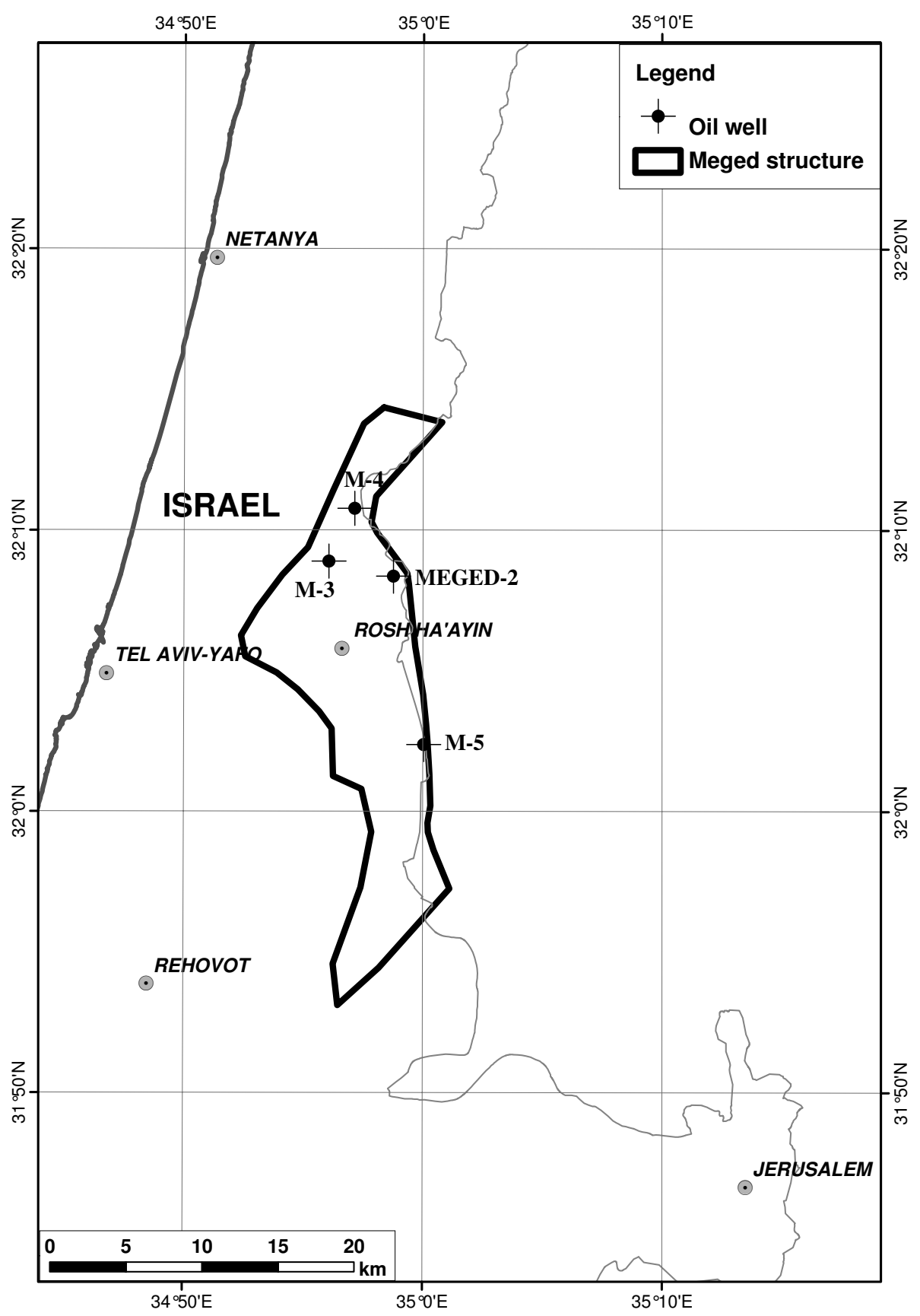

Fig. 2. Location map.

\section{MATERIAL AND METHODS}

Twenty-seven samples of the $5013-5200 \mathrm{~m}$ section of the Meged-2 well were examined for ostracods. Due to the small amount of cuttings in the well archive at the Geological Survey, Jerusalem, only a few grams of sediment could be used for each sample. They were washed after peroxide treatment and all ostracods larger than $150 \mu \mathrm{m}$ were picked. Nineteen samples yielded ostracods in frequencies between five and twenty-three specimens per sample (Fig. 3). Up to eight different species could be observed in the $5126 \mathrm{~m}$ sample. In total, more than 300 specimens were found. Only closed carapaces occur, so that internal features could not be examined. Most taxa are adult forms and are rather well preserved; juveniles are very rare and occur only in species of the genus Bairdia. Selected specimens were photographed with the Jeol (JSM-840) scanning electron microscope at the GSI, Jerusalem, after carbon and gold coating. Additional material was photographed at the UPMC, Paris, with the Hitachi (TM-1000) SEM without coating.

The fauna comprises seventeen species, belonging to eleven genera. Many forms were hitherto not described in the literature. The distribution of the ostracods in the section is presented in Figure 3 and representative forms of all observed species are figured in Plates 1 and 2. Several taxa were described in open nomenclature, mainly because of their rare occurrences in the 


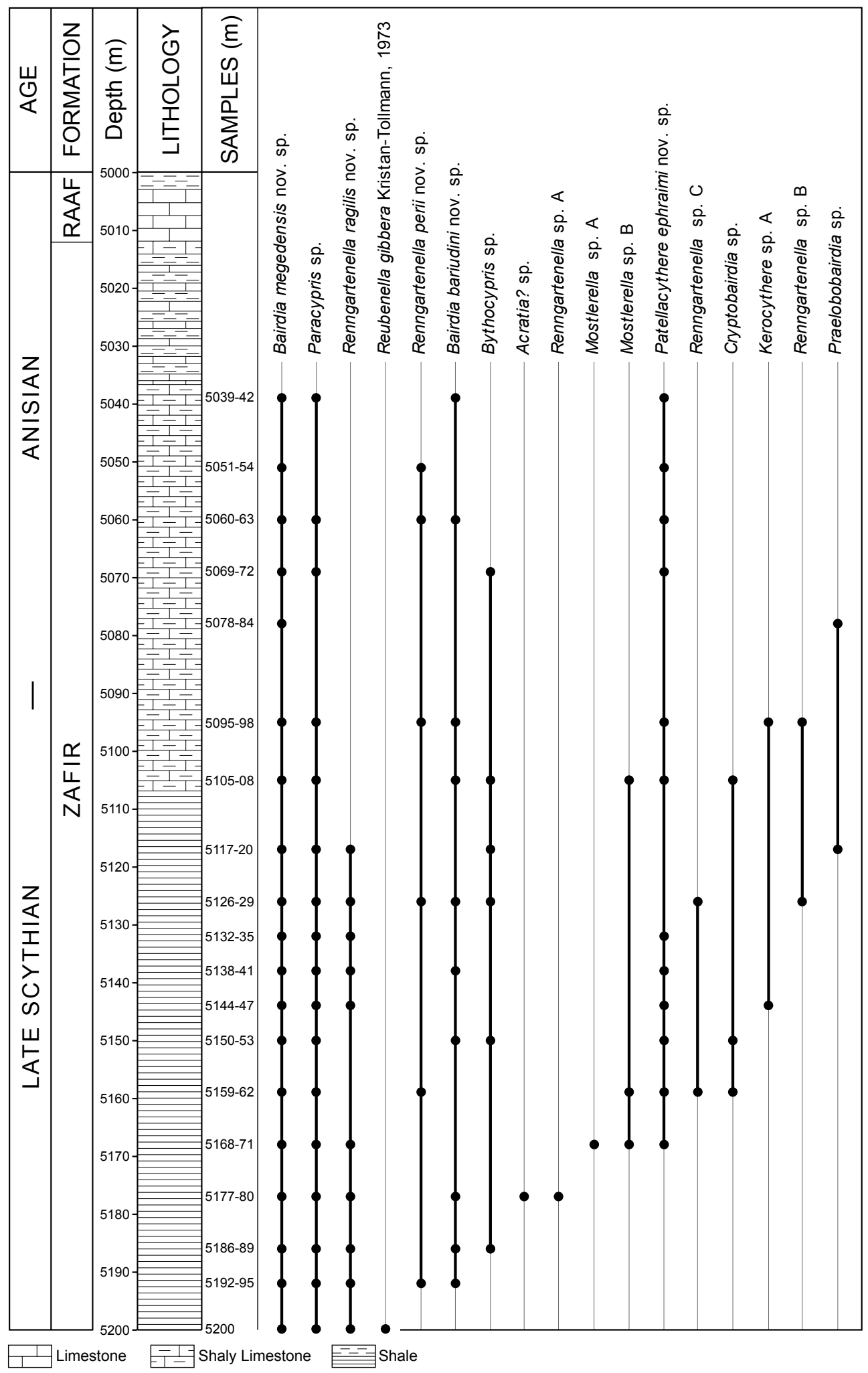

Fig. 3. Distribution chart of ostracods in the Meged-2 borehole section, 5000-5200 m interval (formation and lithology modified after Well Completion Report by Givot Olam (1995)). 
samples, but may represent new species. The low number of ostracods in the samples can be referred to the rather small amount of material of the cuttings from the borehole which was available for this study. All types are stored in the ostracod collections of the Geological Survey of Israel, 30 Malkhe Yisrael St, 95501 Jerusalem, in the section 'Triassic/Meged-2/XXX'.

\section{SYSTEMATIC DESCRIPTION OF OSTRACODS}

Abbreviations: L, length; H, height; $\mathrm{W}$, width; RV, right valve; $\mathrm{LV}$, left valve; $\mathrm{AB}$, anterior border; $\mathrm{PB}$, posterior border; DB, dorsal border; VB, ventral border; ACA, anterior cardinal angle; PCA, posterior cardinal angle; L1-L3, lobes (designated numerically from the anterior to the posterior border); S1-S2, sulci (designated numerically from the anterior to the posterior border).

\author{
Class Ostracoda Latreille, 1806 \\ Subclass Podocopa Müller, 1894 \\ Order Podocopida Müller, 1894 \\ Suborder Podocopina Sars, 1866 \\ Superfamily Bairdioidea Sars, 1887 \\ Family Bairdiidae Sars, 1887 \\ Genus Bairdia McCoy, 1844
}

Bairdia megedensis nov. sp.

(Pl. 1, figs 1-2)

Derivation of name. From Meged-2 borehole, the type locality.

Diagnosis. A new species of Bairdia with compact punctate carapace, $\mathrm{DB}$ regularly arched at $\mathrm{LV}$ and straight at $\mathrm{RV}$; ridge at $\mathrm{AB}$; strong overlap of LV on RV.

Holotype. One complete carapace (Pl. 1, fig. 1), collection no. Triassic/Meged-2/479.

Paratype. One complete carapace (Pl. 1, fig. 2), collection no. Triassic/Meged-2/506.

Material. About 150 carapaces from all ostracod-bearing samples throughout the section (see Fig. 3).

Type locality and stratum. Meged-2 well, E $34^{\circ} 58^{\prime} 45^{\prime \prime}$, N $32^{\circ} 08^{\prime} 22^{\prime \prime}$ (E 686751, N 3557668 - UTM zone 36, WGS84 datum), depth 5144-5147 m, Zafir Formation, Israel.

Description. Compact Bairdiidae carapace with LV regularly arched on all parts, left lateral view very rounded for the genus (see Pl. 1, fig. 2); maximum of curvature of $\mathrm{AB}$ located at mid-height and of PB located at the lower third of height or a little above; maximum of height located at mid-length. RV: DB, anterodorsal and posterodorsal borders, straight; AB regularly arched with a quite large radius of curvature, presence of a flattening all along the AB; all the parts of VB gently flattened laterally, LV strongly overlaps RV all around the carapace with minimum at posteroventral border and $\mathrm{AB}$; the characteristic 'bairdian' beak is poorly expressed. Carapace punctate on the entire surface except in the median part and on the margins.
Dimensions (mm). Representative specimens.

\begin{tabular}{lccc}
\hline & $\mathrm{L}$ & $\mathrm{H}$ & $\mathrm{W}$ \\
\hline Holotype & 0.70 & 0.43 & \\
Paratype & 0.83 & 0.50 & \\
& 0.71 & & 0.34 \\
& 0.84 & & 0.39 \\
\hline
\end{tabular}

Occurrence. Late Scythian-Anisian (Early-Middle Triassic); Fig. 3.

Remarks. No punctate species of Bairdia were reported hitherto from Triassic stages earlier than the Rhaetian. In the Rhaetian, such species as Bairdia ventriosa Bolz, 1971 (p. 158, pl. 4, figs 49-54) or Bairdia margosulcata Bolz, 1971 (p. 174, pl. 6, figs 77-81; both from Austria) are described, which have the same kind of ornamentation with punctations. But, these two species have an outline very different to $B$. megedensis nov. sp.. The relationship between the two valves and the general outline is characteristic and no other species are really close.

\section{Bairdia bariudini nov. sp.}

(P1. 1, figs 3-5)

Derivation of name. In honour of Dr. Victor Bariudin, Oil and Gas Section, Ministry of National Infrastructures, Jerusalem, Israel.

Diagnosis. A new species of Bairdia with triangular general outline and very angular DB.

Holotype. One complete carapace (Pl. 1, fig. 3), collection no. Triassic/Meged-2/4511.

Paratype. One complete carapace (P1. 1, fig. 4), collection no. Triassic/Meged-2/4514.

Material. Eleven carapaces throughout the section.

Type locality and stratum. Meged-2 well, E $34^{\circ} 58^{\prime} 45^{\prime \prime}, \mathrm{N}$ $32^{\circ} 08^{\prime} 22^{\prime \prime}$ (E 686751, N 3557668 - UTM zone 36, WGS84 datum), depth 5177-5180 m, Zafir Formation, Israel.

Description. Compact Bairdiidae carapace. LV: all dorsal parts straight, angle between DB and ADB: $120-130^{\circ}$; angle between DB and PDB: $145-160^{\circ}$; AB regularly arched with maximum of curvature located at mid-H; PB quite rounded, 'bairdian' beak poorly marked, maximum of curvature at lower third of $\mathrm{H}$; VB nearly straight. RV: all dorsal parts straight; angle between DB and anterodorsal: $140-145^{\circ}$; angle between DB and posterodorsal: $145-150^{\circ}$; VB concave; PB gently flattened laterally. Surface punctate except on $\mathrm{AB}$ and $\mathrm{PB}$. 

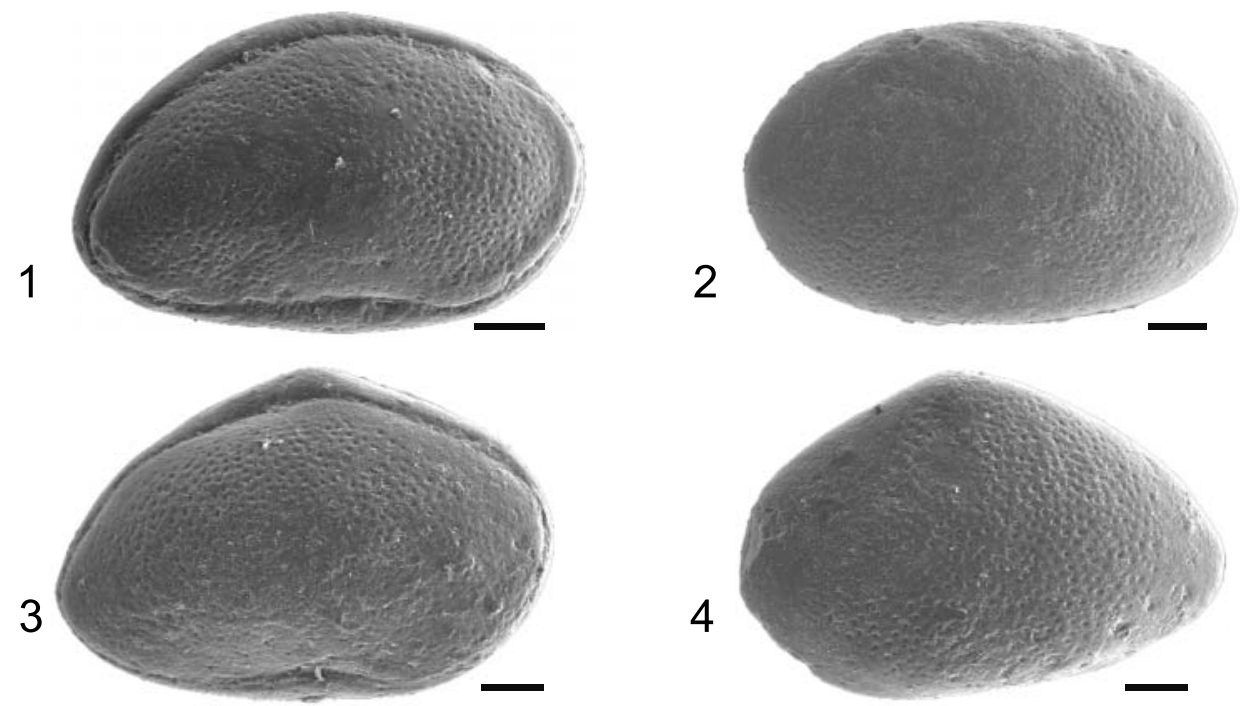

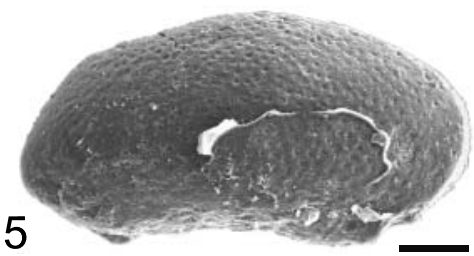

6
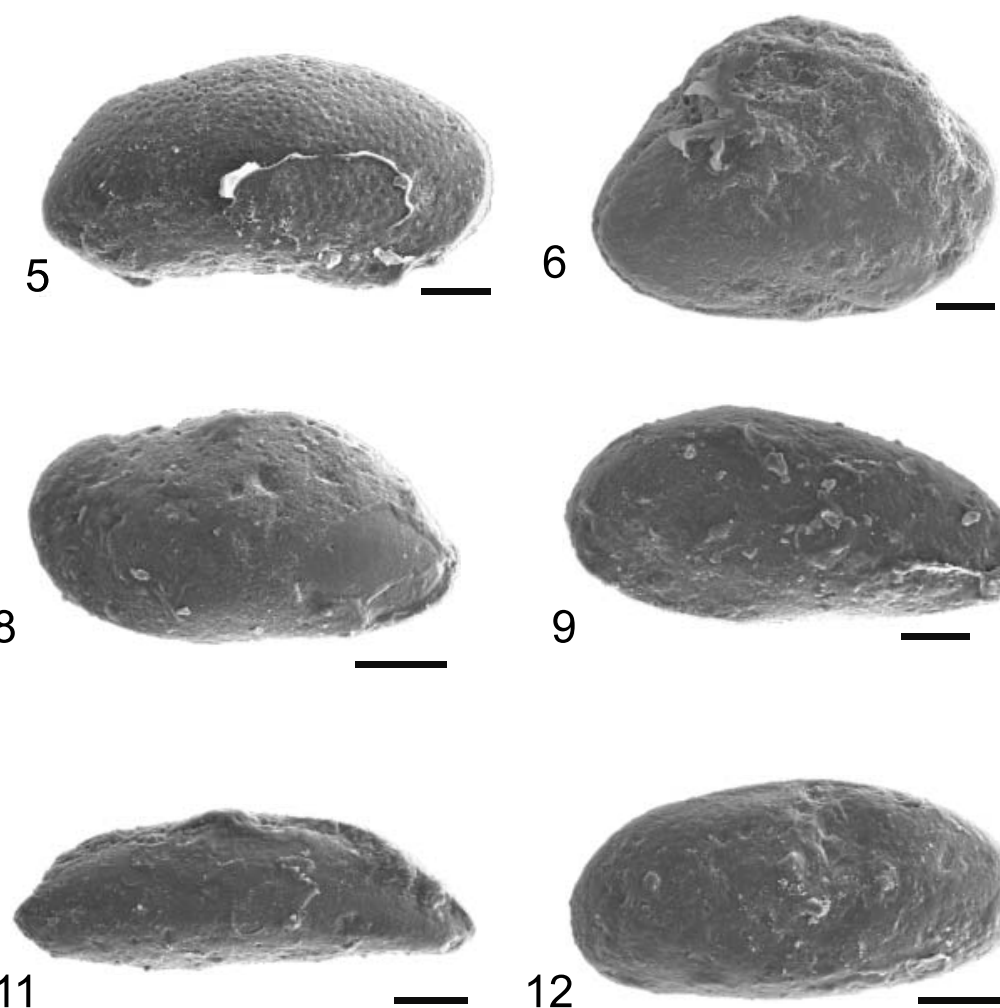
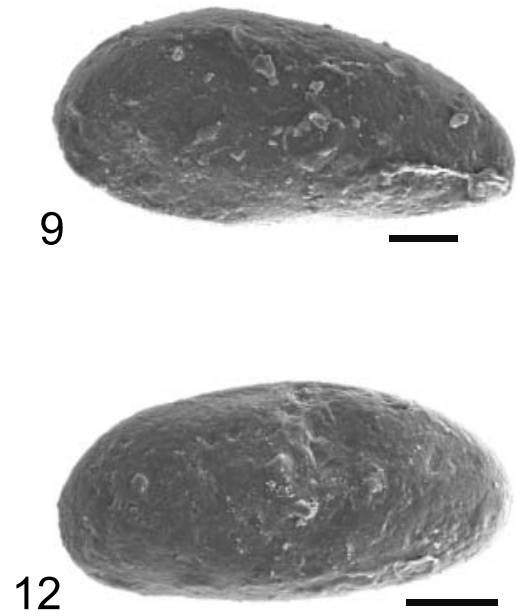

13
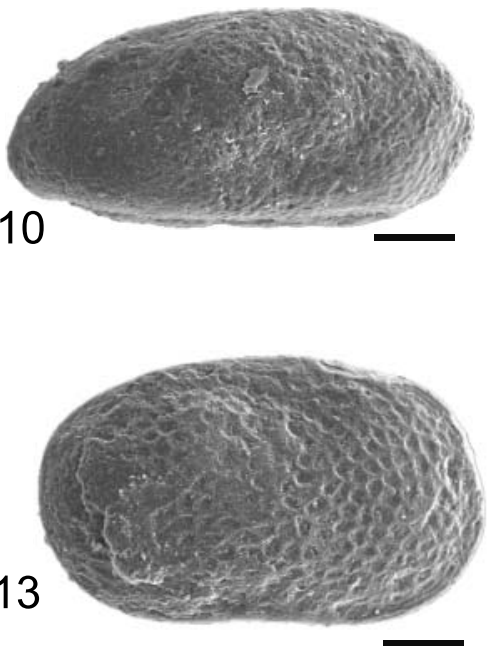

Explanation of Plate 1.

Ostracods from the Meged-2 section. All SEM micrographs are lateral views of carapaces. figs 1, 2. Bairdia megedensis nov. sp.: 1, holotype, complete carapace, right lateral view, 5144-5147 m, collection no. 479; 2, paratype, complete carapace, left lateral view, 5069-5072 m, collection number 506. figs 3-5. Bairdia bariudini nov. sp.: 3, holotype, complete carapace, right lateral view, 5177-5180 m, collection no. 4511; 4, paratype, complete carapace, left lateral view, 5177-5180 m, collection no. 4514; 5, corroded carapace (left valve not preserved), right lateral view, 5039-5042 m, collection no. 533. figs 6, 7. Praelobobairdia sp.: 6, complete carapace, right lateral view, 5117-5120 m, collection no. 4816; 7, complete (?) carapace, left lateral view, 5078-5084 m, collection no. 503. fig. 8. Cryptobairdia sp., complete (?) carapace, left lateral view, 5150-5153 m, collection no. 474 . figs 9, 10. Paracypris sp., complete carapace: 9, left lateral view, $5200 \mathrm{~m}$, collection no. 442; 10, right lateral view, $5168-5171 \mathrm{~m}$, collection no. 466. fig. 11. Acratia? sp., broken carapace at AB, left lateral view, 5177-5180 m, collection no. 459. fig. 12. Bythocypris sp., complete carapace, left lateral view, 5126-5129 m, collection no. 4811. fig. 13. Reubenella gibbera Kristan-Tollmann, 1973, complete carapace, right lateral view, 5200 m, collection no. 444. Scale bar $200 \mu \mathrm{m}$ for all figures. All types are stored in the ostracod collections of the Geological Survey of Israel, 30 Malkhe Yisrael St, 95501 Jerusalem, in the section 'Triassic/Meged-2/XXX'. 

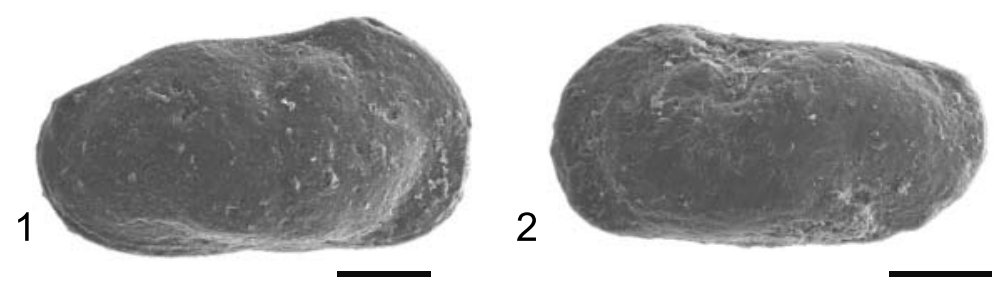

3
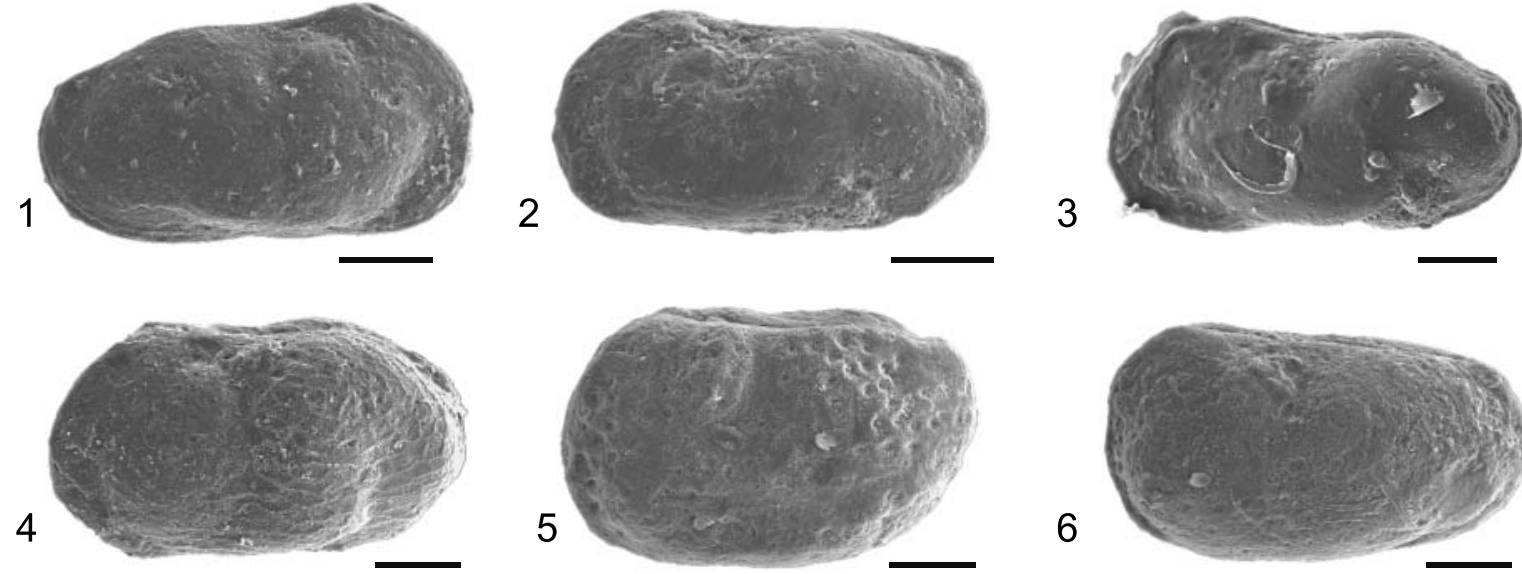

6
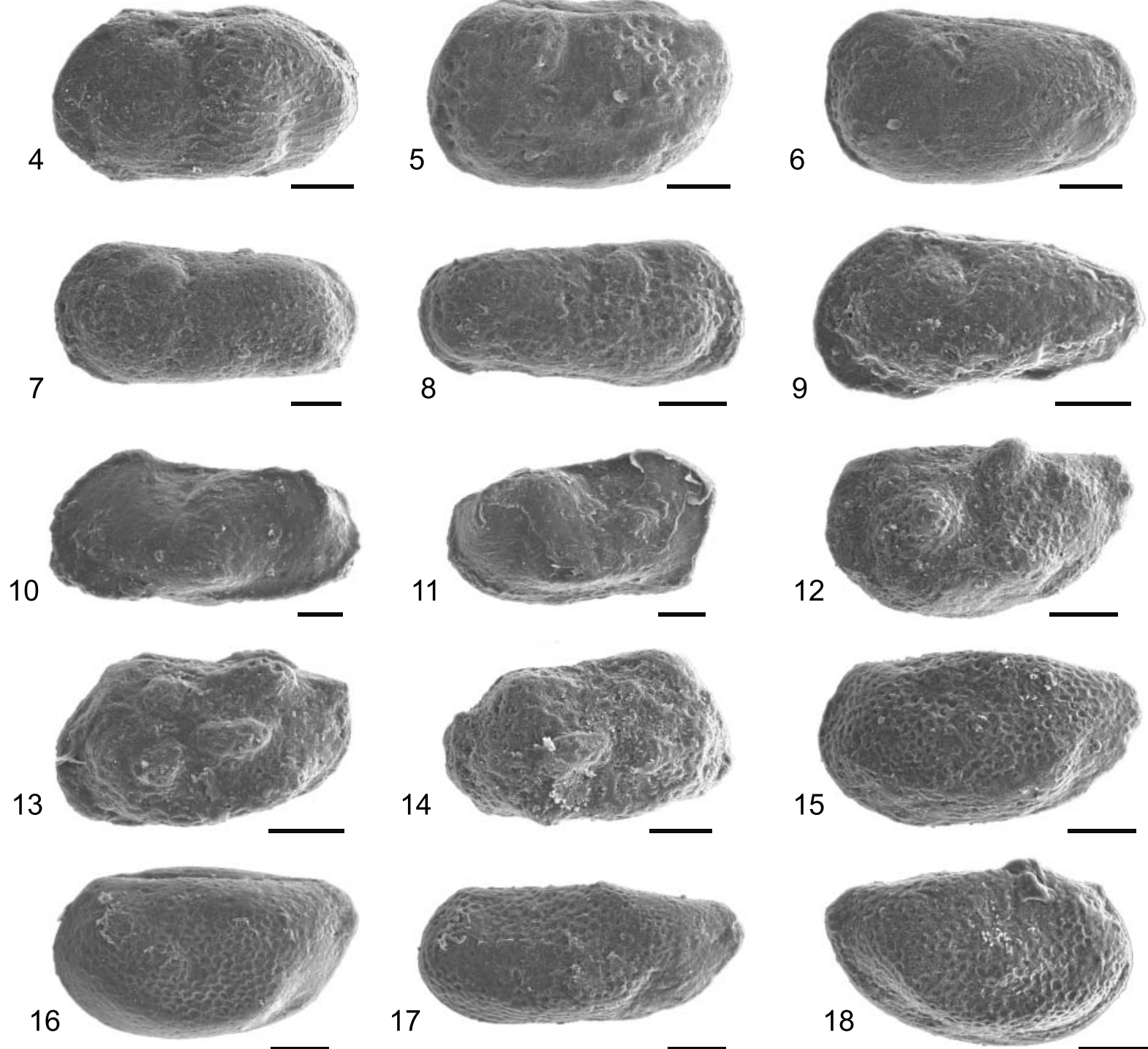

\section{4}
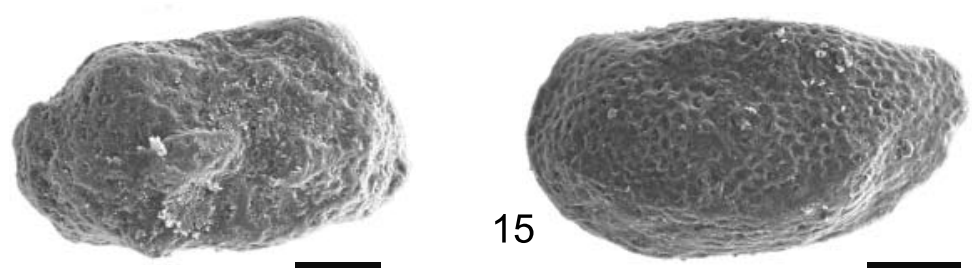

17

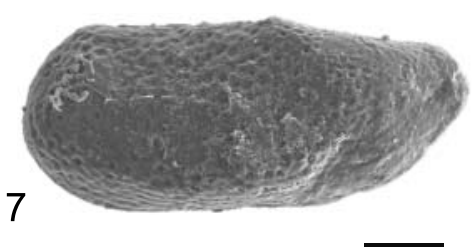

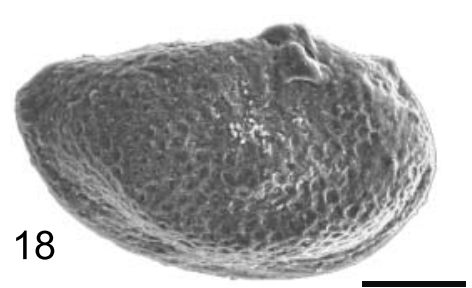

Explanation of Plate 2.

Ostracods from the Meged-2 section. All SEM micrographs are lateral views of carapaces. figs 1-3. Renngartenella ragilis nov. sp.: 1, holotype, complete ? ô carapace, right lateral view, 5138-5141 m, collection no. 484; 2, paratype, complete ? đo carapace, left lateral view, 5177-5180 m, collection no. 4815; 3, paratype, complete ? 9 carapace, left lateral view, 5192-5195 m, collection no. 4412A. fig. 4. Renngartenella sp. A, complete carapace, left lateral view, 5177-5180 m, collection no. 4510. figs 5, 6. Renngartenella sp. B: 5, complete + carapace, left lateral view, 5095-5098 m, collection no. 4910; 6, complete o carapace, left lateral view, 5126-5129 m, collection no. 4810. figs 7, 8. Renngartenella sp. C, complete carapace: 7, left lateral view, 5159-5162 m, collection no. 4612; 8, right lateral view, 5126-5129 m, collection no. 4812. fig. 9. Kerocythere sp. A, complete carapace, left lateral view, 5144-5147 m, collection no. 4710. figs 10, 11. Renngartenella perii nov. sp.: 10, holotype, complete ô carapace, left lateral view, 5095-5098 m, collection no. 497; 11, paratype, o carapace partly broken at AB, right lateral view, 5060-5063 m, collection no. 508. fig. 12. Mostlerella sp. A, complete carapace, left lateral view, $5168-5171 \mathrm{~m}$, collection no. 461. figs 13, 14. Mostlerella sp. B, complete carapace: 13, left lateral view, 5105-5108 m, collection no. 495; 14, right lateral view, 5159-5162 m, collection no. 469. figs 15-18. Patellacythere ephraimi nov. sp.: 15, paratype, complete $q$ carapace, left lateral view, $5168-5171 \mathrm{~m}$, collection no. 464; 16, holotype, complete $q$ carapace, left lateral view, 5105-5108 m, collection no. 491; 17, paratype, complete ô carapace, left side view, 5105-5108 m, collection no. 492; 18, paratype, complete $\$$ carapace, right side view, 5150-5153 m, collection no. 473. Scale bar $200 \mu \mathrm{m}$ for all figures. All types are stored in the ostracod collections of the Geological Survey of Israel, 30 Malkhe Yisrael St, 95501 Jerusalem, in the section 'Triassic/Meged-2/XXX'. 
Dimensions (mm).

\begin{tabular}{lcc}
\hline & $\mathrm{L}$ & $\mathrm{H}$ \\
\hline Holotype & 0.78 & 0.52 \\
Paratype & 0.76 & 0.50 \\
& 0.62 & 0.30 \\
\hline
\end{tabular}

Occurrence. Late Scythian-Anisian (Early-Middle Triassic); samples 5039 to 5192 m; Fig. 3.

Remarks. Bairdia bariudini nov. sp. is very close to Bairdia megedensis nov. sp. (see above). Bairdia bariudini nov. sp. has a more triangular outline and no ridge along $\mathrm{AB}$. The corroded carapace, figured here as Plate 1, fig. 5 may represent a juvenile form of the species.

\section{Genus Praelobobairdia Kozur, 1985 \\ Praelobobairdia sp. \\ (Pl. 1, figs 6-7)}

Material. Two carapaces.

Dimensions (mm). L: 0.63-0.64; H: 0.48-0.49.

Occurrence. Late Scythian-Anisian (Early-Middle Triassic); $5117 \mathrm{~m}$ and $5078 \mathrm{~m}$ samples; Fig. 3.

Remarks. The specimens are poorly preserved and it is difficult to observe specific characters.

\section{Genus Cryptobairdia Sohn, 1960 \\ Cryptobairdia $\mathrm{sp.}$}

(P1. 1, fig. 8)

Material. Three specimens.

Description. Cryptobairdia with long and poorly arched DB; AB with large radius of curvature; maximum of convexity located at the upper third of $\mathrm{H}$; VB nearly straight to gently concave at both valves; $\mathrm{PB}$ weakly tapering with maximum of curvature located low; LV overlaps RV faintly all around the carapace.

Dimensions (mm). L: 0.46; H: 0.25.

Occurrence. Late Scythian-Anisian (Early-Middle Triassic); 5159-5105 m samples; Fig. 3.

Genus Acratia Delo, 1930

Acratia? sp.

(P1. 1, fig. 11)

Material. One damaged carapace.

Dimensions (mm). L: 0.62?; H: 0.21 .
Occurrence. Late Scythian-Anisian (Early-Middle Triassic); 5177 m sample; Fig. 3.

Remarks. This very elongated carapace ( $\mathrm{L} / \mathrm{H}: 2.95)$ is damaged and it is rather difficult to be more precise in determination. Kolar-Jurkovsek (1991, pl. 4, fig. 2; Middle Triassic of Slovenia) figured a specimen which has a similar general outline, but a more rounded $\mathrm{AB}$. In our specimen, the $\mathrm{AB}$ is broken.

Genus Bythocypris Brady, 1880

Bythocypris sp.

(P1. 1, fig. 12)

Material. Ten carapaces.

Description. Small carapace elongated (L/H: 1.95) with straight $\mathrm{DB}$; long anterodorsal part; $\mathrm{AB}$ with quite small radius of curvature, maximum of curvature located a little below mid $\mathrm{H}$; VB straight to gently concave; $\mathrm{PB}$ with quite large radius of curvature for the genus; maximum $\mathrm{H}$ located in front of mid $\mathrm{L}$. Surface smooth.

Dimensions (mm). L: $0.50-0.54 ; \mathrm{H}: 0.24-0.30$.

Occurrence. Late Scythian-Anisian (Early-Middle Triassic); $5168 \mathrm{~m}$ to $5069 \mathrm{~m}$ samples; Fig. 3.

Superfamily Cypridoidea Baird, 1845

Genus Paracypris Sars, 1866

Paracypris sp.

(Pl. 1, figs 9-10)

Material. About 75 carapaces.

Description. Elongated carapace of Paracypris with long straight $\mathrm{DB}$; AB semicircular, with maximum of curvature located at mid-H; VB long, almost straight; PB with small radius of curvature, dorsal part quite vertical, maximum of curvature located close to ventral part; $\mathrm{H}$ maximum at anterior part of $\mathrm{DB}$; presence of a node in dorso-posterior part of the carapace; carapace flattened laterally at $\mathrm{AB}$ and $\mathrm{PB}$. LV overlaps $\mathrm{RV}$ on free margins. Surface smooth to punctate.

Dimensions (mm). L: 0.57-0.63; H: 0.27-0.29.

Remarks. Our specimens seem to be nearly identical to those reported by Sohn (1968, p. 31, pl. 2, figs 30-34) as Paracypris? sp. 2 (Anisian-Ladinian of Israel).

Occurrence. Late Scythian-Anisian (Early-Middle Triassic); all samples; Fig. 3.

Superfamily Cytheroidea Baird, 1850

Family Bythocytheridae Sars, 1926

Genus Patellacythere Gründel \& Kozur, 1972

Patellacythere ephraimi nov. sp.

(P1. 2, figs 15-18) 
1974 Triebacythere nov. sp.?; Hirsch \& Gerry: pl. 2, fig. 5.

Derivation of name. In honour of the late Ephraim Gerry, Tel Aviv, who worked on the ostracods from nearly all Triassic borehole sections in Israel.

Diagnosis. A species of Patellacythere with low lobes and bowl-like S2, subround reticulation pattern and pronounced sexual dimorphism.

Holotype. One 9 carapace (Pl. 2, fig. 16), collection no. Triassic/ Meged-2/491.

Paratypes. One $\widehat{\delta}$ and two $q$ carapaces (Pl. 2, figs 15, 17-18), collection nos Triassic/Meged-2/464, 492, 473.

Material. Twenty carapaces.

Type locality and stratum. Meged-2 well, E $34^{\circ} 58^{\prime} 45^{\prime \prime}, \mathrm{N}$ $32^{\circ} 08^{\prime} 22^{\prime \prime}$ (E 686751, N 3557668 - UTM zone 36, WGS84 datum), depth 5105-5108 m, Zafir Formation.

Description. Small to medium-sized subrectangular carapace. $\mathrm{AB}$ regularly arched with maximum of curvature located at mid $\mathrm{H}$; VB regularly curved in $q$ carapaces, quite straight and parallel to $\mathrm{DB}$ in $\sigma^{\star}$ carapaces; $\mathrm{PB}$ with very small radius of curvature and maximum of curvature located at upper third of $\mathrm{H}$ or above; DB convex, over-reaching hinge line. Only S2 is visible and bowl-like (patelliform), extending to the central area; presence of a ventral elongated lobe. Carapace flattened laterally all along free margins. Dorsal view subrhombical with extremities compressed. Ornamentation composed of small rhomboid to subround reticulation patterns all over the carapace, except the nearly smooth posterodorsal region. Sexual dimorphism pronounced: $\widehat{t}$ much narrower and longer $(\mathrm{L} / \mathrm{H}$ : 2.3) than ㅇ ( $\mathrm{L} / \mathrm{H}: 1.8-2.0)$.

Dimensions (mm).

\begin{tabular}{|c|c|c|c|}
\hline & $\mathrm{L}$ & $\mathrm{H}$ & W \\
\hline Holotype o & 0.50 & 0.25 & 0.26 \\
\hline Paratype ${ }^{\star}$ & 0.55 & 0.24 & \\
\hline Paratype $q$ & 0.47 & 0.26 & \\
\hline Paratype $q$ & 0.42 & 0.23 & \\
\hline q & 0.47 & 0.26 & 0.25 \\
\hline
\end{tabular}

Occurrence. Late Scythian-Anisian (Early-Middle Triassic); samples $5168 \mathrm{~m}$ and above; Fig. 3.

Remarks: Our specimens seem to be identical with Triebacythere sp. nov.? of Hirsch \& Gerry (1974) from the Scythian of Israel. Gründel \& Kozur (1972, p. 936) defined the lack of the broad ventrolateral lobe and the absence of the antero- and posterodorsal nodes in Patellacythere as the main external features that distinguish this genus from the similar genus Triebacythere Gründel \& Kozur, 1972. Following this assumption, we grouped the specimens described here into the genus Patellacythere, where they may represent one of the oldest species of the genus, which occurs from the Middle Triassic to the Neogene (Gründel \& Kozur, 1972, p. 920). Patellacythere ephraimi nov. sp. resembles P. minuta (Kozur, 1968) (p. 506, pl. 2, figs 4-5, 8-10, 12-13; Ladinian of Germany), but this species shows a rather broad ventral lobe and should, therefore, be grouped into the genus Triebacythere, as discussed above. Transitional forms between the two genera may occur and the genera sometimes cannot be differentiated on the basis of external features only. $P$. spitiensis Kozur, 1984 (in Goel et al. 1984, p. 54, pl. 1, figs 7-8; Anisian of India) is very close to $P$. ephraimi nov. sp., but is somewhat larger and shows a much deeper and wider sulcus. Monoceratina loferensis Urlichs, 1972 (p. 676, pl. 1, figs 9-14; Norian of Germany) is also very similar to our species, but differs in the shape of the PB and possesses a more pronounced ventral lobe.

Family undetermined

Genus Renngartenella Schneider, 1957 (in Mandelstam et al., 1957)

Renngartenella ragilis nov. $\mathrm{sp}$.

(P1. 2, figs 1-3)

1974 Monoceratina sp. C ?; Hirsch \& Gerry: pl. 2, fig. 6.

Derivation of name. From 'ragil - רגיל', Hebrew word for normal, regular, from its frequent occurrence in the section.

Diagnosis. A species of Renngartenella with low lobes and sulci; smooth surface.

Holotype. One ${ }^{\star}$ ? carapace (Pl. 2, fig. 1), collection no. Triassic/ Meged-2/484.

Paratypes. One ${ }^{\star}$ ? and one $q$ ? carapace (P1. 2, figs 2, 3), collection nos Triassic/Meged-2/4815, 4412.

Material. About 25 carapaces.

Type locality and stratum. Meged-2 well, E $34^{\circ} 58^{\prime} 45^{\prime \prime}$, N $32^{\circ} 08^{\prime} 22^{\prime \prime}$ (E 686751, N 3557668 - UTM zone 36, WGS84 datum), depth 5138-5141 m, Zafir Formation.

Description. Small to medium-sized carapace, subrectangular, elongated (L/H: 1.9). AB with large radius of curvature, maximum of curvature located below mid $\mathrm{H}$; VB straight to gently concave; $\mathrm{PB}$ with radius of curvature smaller than $\mathrm{AB}$, maximum of curvature located at mid $\mathrm{H}$ or a little below; $\mathrm{DB}$ straight; cardinal angles well defined (ACA: 145-150 ${ }^{\circ}$ PCA: $\left.125-135^{\circ}\right)$. Lobes and sulcus poorly expressed, L1 and S1 practically invisible, L2 rounded and located at the anterior third of $\mathrm{L}$ and upper quarter of $\mathrm{H}, \mathrm{S} 2$ shallow and short, ended at upper third of $\mathrm{H}$, L3 large and reaching over dorsal margin, ventral lobe visible, but poorly developed for the genus, over-reaching the ventral margin; carapace flattened all along free margins on a large zone; LV overlaps RV along free margins. Surface smooth. Dorsal view subovoid, elongated with 
compressed ends. Sexual dimorphism suspected: females swollen in the centroposterior part.

Dimensions (mm).

\begin{tabular}{|c|c|c|c|}
\hline & $\mathrm{L}$ & $\mathrm{H}$ & W \\
\hline Holotype đ?? & 0.46 & 0.24 & \\
\hline Paratype $₫ ?$ & 0.42 & 0.21 & \\
\hline \multirow[t]{3}{*}{ Paratype $9 ?$} & 0.51 & 0.27 & \\
\hline & 0.49 & 0.25 & 0.24 \\
\hline & 0.40 & & 0.22 \\
\hline
\end{tabular}

Occurrence. Late Scythian-Anisian (Early-Middle Triassic); $5200 \mathrm{~m}$ to $5117 \mathrm{~m}$ samples; Fig. 3.

Remarks. Renngartenella ragilis nov. sp. seems to be identical to Monoceratina sp. C ? sensu Hirsch \& Gerry (1974) from the Early Scythian of Israel, but only one figure of a slightly tilted form is given in the paper. Our species resembles Renngartenella santaecrucis Kristan-Tollmann, 1973 (in Kristan-Tollmann \& Hamedani, 1973, p. 215, pl. 8, figs 1-6; pl. 11, figs 1, 3, 5, 6; pl. 12, fig. 10; Carnian of Austria) in outline and by the position of the sulcus, but differs in the arrangement of lobes. Here, the lobes and sulci are less pronounced and the surface is smooth. In addition, a number of seemingly different species are described by various authors as $R$. santaecrucis (see remarks on Renngartenella sp. A in this paper). The similar forms of $R$. clivosa Kristan-Tollmann, 1983 (p. 155, pl. 7, figs 7-9; Anisian of China) have additional nodes than our species and in $R$. exilicosta Kristan-Tollmann, 1983 (p. 155, pl. 12, figs 3, 5-9; Anisian of China) a rather prominent ventral lobe occurs. Lutkevichinella keuperea (Will, 1969) from the Norian of Germany (Urlichs, 1972, p. 679, pl. 3, figs 1-5) and the Norian of Italy (Crasquin-Soleau et al., 2000, p. 186, pl. 1, figs 9-12) has a similar outline and other carapace features, but develops prominent central and midventral tubercles.

\section{Renngartenella sp. A}

(P1. 2, fig. 4)

Material. One carapace.

Dimensions (mm). L: 0.48; H: 0.26; W: 0.27 .

Occurrence. Late Scythian-Anisian (Early-Middle Triassic); 5117 m; Fig. 3.

Remarks. Renngartenella sp. A is very similar to $R$. ragilis sp. nov. (Pl. 2, figs 1-3), but possesses a delicate net-like and irregular reticulation over the whole surface of the carapace, except at the smooth anterior area. The figured carapace may represent a female specimen, as expressed by the swollen centroposterior part, best seen in dorsal view. The rather small differences to $R$. ragilis nov. sp. and the finding of only one carapace in our samples do not allow the erection of a new species and this form, therefore, is left in open nomenclature.
As discussed above in $R$. ragilis nov. sp., Renngartenella sp. A is also similar to some reticulated forms grouped under $R$. santaecrucis Kristan-Tollmann, 1973 (see Gerry et al., 1990, p. 96, pl. 1, figs 11-13; Carnian of Israel; and Basha, 1982, pl. 1, fig. 15; Carnian of Jordan).

\section{Renngartenella sp. B (P1. 2, figs 5-6)}

Material. Two carapaces.

Description. Medium-sized subrectangular carapace. DB straight; $\mathrm{AB}$ broadly rounded with large radius of curvature, maximum of curvature at lower third of $\mathrm{H}$; VB almost straight to gently convex; $\mathrm{PB}$ rounded with smaller radius of curvature than AB; cardinal angles clearly expressed (ACA: $130-140^{\circ}$, PCA: $\left.125-130^{\circ}\right)$. External areas slightly flattened in a narrow zone; greatest $\mathrm{H}$ at ACA. L1 and S1 not visible; L2 rounded located between the anterior third and mid $\mathrm{L}$ and in the upper half of $\mathrm{H}$; S2 clear from DB to mid $\mathrm{H}$, L3 poorly developed ; ventral node not very visible rib from the anterior area to about $2 / 3$ of L. Carapace flattened laterally in antero- and posteroventral parts. Ornamentation of the carapace consists of irregularly dispersed holes, fossae and grooves, mostly rounded. Dorsal view subovoid elongated. Sexual dimorphism: males more elongate and narrower.

Dimensions (mm).

\begin{tabular}{|c|c|c|c|}
\hline & L & $\mathrm{H}$ & W \\
\hline$q$ & 0.50 & 0.28 & 0.25 \\
\hline ot & 0.50 & 0.26 & \\
\hline
\end{tabular}

Occurrence. Late Scythian-Anisian (Early-Middle Triassic); samples $5126 \mathrm{~m}$ and $5095 \mathrm{~m}$; Fig. 3.

Remarks. Renngartenella sp. B differs from $R$. ragilis nov. sp. mainly by its ornamentation pattern. $R$. sp. B resembles forms described by Sohn (1968, p. 26, pl. 1, figs 14, 33) as Gen. undet. B sp. 1 (Ladinian of Israel), but the latter possesses additional nodes.

\section{Renngartenella sp. C}

(Pl. 2, figs 7-8)

Material. Two carapaces.

Description: Medium-sized carapace, subrectangular and elongate (L/H: 2.2). AB and $\mathrm{PB}$ nearly equal and broadly rounded; $\mathrm{DB}$ and VB nearly straight and subparallel; maximum $\mathrm{H}$ in anterior quarter of L. L2 prominent and rounded, located at anterior third of L and in upper third of $\mathrm{H}$; S2 narrow and short, reaching mid-H; L3 merged into the posterior part of the carapace, not over-reaching $\mathrm{DB}$; long ventral lobe, terminating in a posteroventral node. AB and PB flattened laterally; valves sub-equal. Ornamentation consists of an irregular fine reticulation pattern with subrectangular meshes and small punctations 
over the whole carapace. Dorsal view subrectangular, with parallel flanks, tapered at both ends. Sexual dimorphism uncertain, but both of our specimens may be males according to their narrow shape.

\section{Dimensions (mm).}

\begin{tabular}{cccc}
\hline L & H & W \\
\hline 0.59 & 0.27 & 0.23 \\
0.49 & 0.22 & \\
\hline
\end{tabular}

Occurrence. Late Scythian-Anisian (Early-Middle Triassic); samples 5126 and 5159 m; Fig. 3.

Remarks: Renngartenella sp. C represents the most elongate and narrow species of the forms of the genus described here. This species is somewhat similar to Gen. undet. A sp. 1 of Sohn (1968, p. 25, pl. 1, figs 19-20; Ladinian of Israel), but the latter has a central lobe and a higher posterodorsal lobe.

\section{Renngartenella perii nov. sp.}

(Pl. 2, figs 10-11)

Derivation of name. In honour of Mr Moshe Peri, Geological Survey of Israel, Jerusalem, who initiated this study with much interest.

Diagnosis. A Renngartenella species with strongly compressed and wide $\mathrm{AB}$ and $\mathrm{PB}$, with dorsal part of L3 underlined by a ridge and ventral lobe with a small spine.

Holotype. One ơ carapace (Pl. 2, fig. 10), collection no. Triassic/ Meged-2/497.

Paratype. One + carapace (Pl. 2, fig. 11), collection no. Triassic/ Meged-2/508.

Material. Eight carapaces.

Type locality and stratum. Meged-2 well, E $34^{\circ} 58^{\prime} 45^{\prime \prime}, \mathrm{N}$ $32^{\circ} 08^{\prime} 22^{\prime \prime}$ (E 686751, N 3557668 - UTM zone 36, WGS84 datum), depth 5095-5098 m, Zafir Formation.

Description: Medium-sized subrectangular carapace. AB asymmetrically rounded, maximum of curvature located below mid $\mathrm{H}$, upper part straighter than lower part, strongly flattened laterally in a blade shape over a wide zone; VB more or less straight; $\mathrm{PB}$ more or less equivalent to $\mathrm{AB}$ with a maximum of curvature located higher, flattened laterally with a few small depressions; DB straight with a concavity more or less expressed behind ACA; cardinal angles clearly expressed (ACA: $145-155^{\circ}$, PCA: $\left.120-125^{\circ}\right)$. L1, S1 and L2 merged into the surface of the carapace; V-shaped S2 bent antero-ventrally, ending a $\mathrm{t}$ mid H; L3 large and occupying all the posterior upper half of the carapace, emphasized by a ridge on its upper part, its lower part is subdivided by the posterior extremity of ventral lobe; ventral lobe elongated from anterior third to posterior third of $\mathrm{L}$, presence of a small spine at the maximum of width, over-reaching the ventral margin. Carapace smooth to gently reticulated. Dorsal view is spearhead shape with thickening at ventral lobe level. Distinct sexual dimorphism: males longer and narrower $(\mathrm{L} / \mathrm{H}: 2.1)$ than females $(\mathrm{L} / \mathrm{H}: 1.9)$ and with less swollen ventral node.

Dimensions (mm).

\begin{tabular}{lccc}
\hline & $\mathrm{L}$ & $\mathrm{H}$ & $\mathrm{W}$ \\
\hline Holotype 0 & 0.63 & 0.32 & 0.25 \\
Paratype + & 0.56 & 0.31 & \\
$\stackrel{+}{+}$ & 0.49 & 0.25 & 0.21 \\
\hline
\end{tabular}

Occurrence. Late Scythian-Anisian (Early-Middle Triassic); samples 5051 to 5192 m; Fig. 3.

Remarks. Renngartenella perii nov. sp. is the largest species of this genus in our samples. It differs from $R$. ragilis nov. sp. mainly by the posterodorsal rib, the ventral spine and the shape of the posterior end.

Genus Kerocythere Kozur \& Nicklas, 1970

\section{Kerocythere sp. A}

(Pl. 2, fig. 9)

Material. Two carapaces.

Description. Small to medium-sized carapace subrectangular to subtriangular, elongated (L/H: 2.05). Greatest $\mathrm{H}$ at the anterior third of L; AB asymmetrically rounded, maximum of curvature located at lower third of $\mathrm{H}$, strongly flattened laterally particularly in ventral part; $\mathrm{PB}$ with small radius of curvature, almost vertical in dorsal part; DB straight in the two anterior thirds of $\mathrm{L}$ and sloping in the posterior third; VB straight to concave. S1 visible, orientated from DB to anteroventral border, located at anterior third of $\mathrm{L}$ and ending at upper quarter of $\mathrm{H}$; L2 bulbous, located between anterior third and mid $\mathrm{L}$ and above mid H; S2 well developed at mid L; L3 merged into the posterior part of the carapace. Valves equal. Dorsal view biconvex with compressed anterior end. Reticulation pattern unclear due to preservation of the specimens; small pits and fine rectangular reticulation seem to appear.

Dimensions (mm).

\begin{tabular}{cccc}
\hline L & H & W \\
\hline 0.42 & 0.21 & 0.17 \\
0.40 & 0.19 & \\
\hline
\end{tabular}

Occurrence. Late Scythian-Anisian (Early-Middle Triassic); samples $5144 \mathrm{~m}$ and $5095 \mathrm{~m}$; Fig. 3.

Remarks. Our specimens may represent a new species of the genus Kerocythere, but the slightly corroded carapaces, the 
rather bad preservation of the ornamentation and the low number of specimens in our material led the authors to leave these forms in open nomenclature. Kerocythere sp. A resembles in its outline K. raibliana (Gümbel, 1869) (see Kozur \& Nicklas, 1970), but lacks the prominent eye-spot and the distinct straight ventral rib. K. raibliana was reported, among other authors, by Urlichs (1972, p. 685, pl. 2, figs 9-15; Carnian of Germany), Kolar-Jurkosvek (1991, p. 84, pl. 14, fig. 5; Ladinian-Carnian of Slovenia) and Monostori (1994, p. 319, pl. 5, figs 5 (1-3), 6 (4); Carnian of Hungary).

Genus Mostlerella Kozur, 1971 (in Bunza \& Kozur, 1971)

$$
\text { Mostlerella sp. A }
$$$$
\text { (Pl. 2, fig. 12) }
$$

Material. One carapace.

Description. Carapace compact (L/H: 1.87). DB straight; AB with large radius of curvature, maximum of curvature located at mid $\mathrm{H}$; VB regularly curved, maximum of $\mathrm{H}$ located in front of mid L; PB with very small radius of curvature, maximum curvature located at upper quarter of $\mathrm{H}$, extended posterodorsally; ACA: $110^{\circ}$; PCA: $125^{\circ}$; AB and PB flattened laterally. L1, L2, L3 bulbous and clearly visible; L1 located at upper quarter of $\mathrm{H}$ and anterior quarter of L; L2 located at anterior third of $\mathrm{L}$ and between upper third and mid $\mathrm{H}$; L3 located above the upper third of $\mathrm{H}$ and between mid $\mathrm{L}$ and posterior third of L, over-reaching DB; S2 large and deep, going from $\mathrm{DB}$ to lower third of $\mathrm{H}$; presence of the fourth bulbous lobe at lower third of $\mathrm{H}$ and posterior third of $\mathrm{L}$. Carapace flattened at $\mathrm{AB}$ and $\mathrm{PB}$ and equivalved. Surface reticulated with irregular meshes and some smooth areas at $\mathrm{AB}$ and $\mathrm{PB}$ and possibly on L3. Dorsal view biconvex with compressed extremities and strongly emergent lobes.

Dimensions (mm). L: 0.45; H, 0.24; W, 0.25 .

Occurrence. Late Scythian-Anisian (Early-Middle Triassic); 5168 m sample; Fig. 3.

Remarks. In our section, only one carapace of Mostlerella sp. A was observed. $M$. sp. A resembles $M$. sinica Kristan-Tollmann, 1983 (p. 154, pl. 8, figs 9-10; pl. 11, figs 1-6; pl. 14, fig. 12; Anisian of China), but the latter is smaller and more elongate and possesses a slightly different pattern of lobes and tubercles. M. nodosa nodosa Kozur, 1971 (in Bunza \& Kozur, 1971, p. 38, pl. 4, figs 10, 12, 14, 16; Carnian of Hungary) is more triangular in lateral view than our species and has a smooth surface. $M$. nodosa parva Kozur 1971 (in Bunza \& Kozur, 1971, p. 39, pl. 4, fig. 2; Carnian of Hungary) and forms figured by KristanTollmann \& Hamedani (1973, pl. 8, figs 10-11; pl. 13, fig. 3; Carnian of Austria) as M. nodosa Kozur, 1971 have a much stronger reticulation and are more elongate than $M$. sp. A. Judahella transita Kozur, 1971 (in Bunza \& Kozur, 1971, p. 27, pl. 4, figs 9, 11, 13; Carnian of Hungary) is an interesting transitional form between the genera Mostlerella and Judahella (same paper, p. 38). This species has a similar outline to our species, but possesses an additional prominent centroventral tubercle.
Mostlerella sp. B

(P1. 2, figs 13-14)

Material. Four carapaces.

Description. Small compact carapace (L/H: 1.85). AB asymmetrically rounded, maximum of curvature located at the lower quarter of $\mathrm{H}$, dorsal part quite straight, strongly flattened laterally in anteroventral part; ACA: $130^{\circ}$. DB straight; PB straight and quite vertical in its upper part and regularly curved in its ventral part; VB slightly convex. L1, L2 and L3 clearly expressed; L1 located in front of anterior quarter of $\mathrm{L}$ and between upper quarter and mid $\mathrm{H}$, connected with a ventral lobe which follows the VB and ends behind posterior quarter of L; L2 bulbous centred at upper quarter of $\mathrm{H}$ and at anterior third of $\mathrm{L}$; L3 elongated anteroposteriorly, located between mid $\mathrm{L}$ and posterior quarter and above the upper quarter of $\mathrm{H}$, overreaching DB. Presence of two other nodes: one elongated anteroposteriorly and located at mid $\mathrm{H}$ and between mid $\mathrm{L}$ and posterior quarter of $\mathrm{L}$; the second bulbous and located at lower quarter of $\mathrm{H}$ and between mid $\mathrm{L}$ and anterior quarter of $\mathrm{L}$. Surface punctate with some irregular grooves and pitted zones on the lobes and nodes.

Dimensions (mm).

\begin{tabular}{lccc}
\hline & $\mathrm{L}$ & $\mathrm{H}$ & $\mathrm{W}$ \\
\hline Holotype & 0.40 & 0.22 & \\
Paratype & 0.41 & 0.23 & \\
& 0.43 & 0.22 & 0.24 \\
\hline
\end{tabular}

Occurrence. Late Scythian-Anisian (Early-Middle Triassic); samples $5168 \mathrm{~m}$ to $5105 \mathrm{~m}$; Fig. 3.

Remarks. Mostlerella sp. B resembles the two subspecies of $M$. blumenthali Kozur, 1974 (in Kozur et al., 1974, p. 40, pl. 2, figs 22-28; Ladinian/Carnian of Spain), but there the arrangement of the lobes and nodes is slightly different and they have a spinal form, may be due to the preservation of the specimens. $M$. blumenthali was also reported from the Carnian of Jordan (Basha, 1982, pl. 1, fig. 16), but only a very unclear illustration of this taxon, without description, was given. $M$. sp. B is similar, but much less elongate than Judahella (Judahella) callosa Kristan-Tollmann, 1983 (p. 147, pl. 8, fig. 8; pl. 11, figs 7-8, 10; Anisian of China). Our species shows also some affinities to Judahella andrusovi Kozur \& Bolz, 1971 (in Bunza \& Kozur, 1971, p. 25, pl. 5, figs 14, 16-22; Norian of Austria). This species was reported from a wide stratigraphical range and geographical distribution (Kristan-Tollmann et al., 1980: Rhaetian of Iran; Urlichs, 1972: Norian of Germany; Kristan-Tollmann, 1983: Anisian of China), so that slightly different taxa may be grouped into the same species. Moreover, the row of equally dominant nodes along the dorsal margin, characteristic for the genus Judahella Sohn, 1968 (see also Bunza \& Kozur, 1971, p. 38) is lacking in our $M$. sp. B. 
Order Platycopida Sars, 1855

Suborder Platycopina Sars, 1865

Genus Reubenella Sohn, 1968

Reubenella gibbera Kristan-Tollmann, 1973

(Pl. 1, fig. 13)

1973 Reubenella gibbera Kristan-Tollmann; Kristan-Tollmann \& Hamedani: 209, pl. 11, figs 7-8; pl. 12, figs 5-7.

1994 Reubenella gibbera Kristan-Tollmann, 1973; Monostori: 314, fig. 3 (5).

Material. One carapace.

Dimensions (mm). L: 0.56; H: 0.33 .

Occurrence. Late Scythian-Anisian (Early-Middle Triassic); 5200 m; Fig. 3.

Remarks. Reubenella gibbera Kristan-Tollmann, 1973 was hitherto reported from the Carnian of Austria (Kristan-Tollmann \& Hamedani, 1973) and Hungary (Monostori, 1994).

\section{RESULTS AND DISCUSSION}

The ostracod assemblage from the lowermost interval in the Meged-2 well (5039-5200 m) is quite unknown in the literature. Moreover, no information on lithological markers and guide macrofossils from nearby wells or surface sections is available. Only closed ostracod carapaces were found; internal features could not be observed. So, future findings of single valves from other locations with hinge and muscle scar information may lead to a revision of the generic positioning of some taxa.

Seventeen species, belonging to eleven genera, are described in this study. Five of them are described as new species. Six species of the genera Renngartenella, Mostlerella and Kerocythere were left in open nomenclature, due to their rare occurrence in the samples, but may also represent new taxa. Only Reubenella gibbera Kristan-Tollmann, 1973 is known from other localities, but from the Carnian. Our assemblages are dominated by Bairdia megedensis nov. sp. and Paracypris sp., which were found in all samples bearing ostracods. Other important species are Renngartenella ragilis nov. sp. from the lower and middle part of the section, as well as Patellacythere ephraimi nov. sp. from the middle and upper part. Punctate species of the genus Bairdia occur in our assemblages ( $B$. megedensis nov. sp. and $B$. bariudini nov. sp.) but punctate Bairdia are otherwise known in the Triassic only from Rhaetian sections. The ostracod fauna in the section points to a normal marine environment of deposition.

As most of the indicative species were not hitherto reported, age definition cannot be based on ostracod ranges from other localities. In Israel, Renngartenella ragilis nov. sp. (formerly called 'Monoceratina' C Hirsch \& Gerry, 1974) and Patellacythere ephraimi nov. sp. (formerly called Triebacythere nov. sp.) were reported from borehole sections in southern Israel containing Late Scythian conodonts. Gerry \& Derin (1981) defined the Scythian by the 'Monoceratina' C ostracod assemblage zone and the Anisian by the Triebacythere ostracod zone (see also Benjamini et al., 2005). This Middle-Late Triassic ostracod zonal subdivision, correlated also with palynological (Eshet, 1990) and foraminiferal data (Gerry \& Derin, 1981; Benjamini, 1984; Korngreen \& Benjamini, 2007; 2011), is widely used for many borehole sections in Israel. Therefore, the occurrence of Renngartenella ragilis nov. sp. in the interval from $5117 \mathrm{~m}$ to $5200 \mathrm{~m}$ in the Meged-2 well would point to a Late Scythian age for this part. The upper part of the section (5039-5105 m), containing Patellacythere ephraimi nov. sp. and above the last occurrence of $R$. ragilis, may be defined as Anisian. No ostracods were found in samples of the uppermost part of the succession (5013-5033 m).

The cutting samples from the Meged-2 well were routinely examined for foraminifera while drilling (Benjamini, 1995). The interval 5012-5045 m was defined as Early Anisian on the basis of the occurrence of Pilammina densa Pantic, 1965 (recorded there as Glomospira densa). As $P$. densa was not observed in the deeper samples down to the TD of the well, the age of this interval was given tentatively as Early Triassic (-?Permian). The Meged-2 samples were re-checked recently for foraminifera and $P$. densa was found in most samples of the $5000 \mathrm{~m}-\mathrm{TD}$ portion of the sequence. Therefore, the age was defined as Anisian by Korngreen \& Benjamini (2011: An3 and An2 subzones) and by B. Derin (Consulting and Geological Services Ltd, Ramat Gan, pers. comm., 2009).

Palynological evidence indicates a probably Late Scythian (-?Anisian) age for the 5003-5156 m section of the well, based on the occurrence of Lunatisporites noviaulensis (Leschik, 1956) and Lunatisporites pellucidus (Goubin, 1965). The architarchs Veryhachium and Baltisphaeridium point to a marine palaeoenvironment. Endosporites papillatus Jansonius, 1962, the type fossil for the Scythian palynozone (Eshet, 1990), was not found in the Meged-2 samples (B. Conway, GSI, Jerusalem, pers. comm., 2009).

Based on these data from different microfossil groups, we suggest a Late Scythian-Anisian age for the ostracod assemblages described here, but this age definition remains uncertain pending discovery of the same fauna in better dated sections.

The results of this study are biostratigraphically significant for the Palaeozoic-Mesozoic turnover of the ostracod taxa. None of the forms presented here exhibit Palaeozoic affinities. The specimens described from the Meged-2 borehole belong to typically Mesozoic genera (Renngartenella, Mostlerella, Patellacythere), which are not present in other localities of the same time interval (Guangxi, South China, Crasquin-Soleau et al., 2006; Pakistan, Sohn, 1970; Germanic Basin, Kozur, 1973a, b; Romania, Crasquin-Soleau \& Gradinaru, 1996 and unpublished data; Far East Russia, Gramm, 1995). Therefore, the turnover of the ostracod fauna (Fig. 1) was completed only during the Late Spathian. Representatives of Palaeozoic forms, as found in Guangxi, Pakistan and Romania, are the very last species in assemblages, which dominated before the boundary at $252 \mathrm{Ma}$.

\section{ACKNOWLEGEMENTS}

The authors thank the reviewers, I. D. Boomer (Birmingham, UK) and A. R. Lord (Frankfurt/M., Germany) for their helpful comments. M. Peri (Geological Survey of Israel, Jerusalem) initiated this study. Y. Druckman and A. Rosenfeld (both GSI) are thanked for many helpful comments on Triassic stratigraphy and ostracods from Israel. W. Mette (Innsbruck, Austria) and 
H. Kozur (Budapest, Hungary) contributed their remarks on the ostracod faunas described here in a preliminary stage of the study. D. Korngreen, B. Conway (both GSI) and B. Derin (Ramat Gan, Israel) rechecked the samples from this section and provided unpublished data on foraminifera and palynology. M. Dvoracheck (GSI) and M.-B. Forel (UCPM, Paris) took the SEM micrographs, M. Qitin (GSI) provided the washed samples. A. Lethiers (UCPM, Paris) and S. Varshavski (Ministry National Infrastructures, Jerusalem) prepared the figures. This paper is part of A. Honigstein's GSI project 40416.

\section{Manuscript received 18 November 2010 \\ Manuscript accepted 20 January 2011}

Scientific editing by Alan Lord

\section{REFERENCES}

Basha, S.H.S. 1982. Microfauna from the Triassic rocks of Jordan Revue de Micropaléontologie, 25: 3-11.

Benjamini, C. 1984. Foraminifera from the Ra'af Formation (Anisian), Har 'Arief, Western Negev, Israel. In Benthos 83, 2nd International Symposium on Benthic Foraminifera, Pau, April 1983: 35-40.

Benjamini, C. 1995. Meged-2, Paleontology report. In Givot Olam, Meged-2 - Well Completion Report, Vol. 2: Appendix 7.

Benjamini, C, Hirsch, F. \& Eshet, Y. 2005. The Triassic in Israel. In: Hall, J.K., Krasheninnikov, V., Hirsch, F., Benjamini, C. \& Flexer, A. (Eds), Geological Framework of the Levant, Vol. II: The Levantine Basin and Israel. Historical Productions-Hall, Jerusalem, 331-360.

Bolz, H. 1971. Die Zlambach - Schichten (alpine Obertrias) unter besonderer Berücksichtigung der Ostrakoden, 1: Ostrakoden der Zlambach - Schichten, besonders Bairdiidae. Senckenbergiana lethaea, 52: 129-283.

Brady, G.S. 1880. Report on the ostracoda dredged by the H.M.S Challenger during the years 1873-1876, Report Voyage Challenger. Zoology, 1(3): 1-184.

Bunza, G. \& Kozur, H. 1971. Beiträge zur Ostracodenfauna der tethyalen Trias. Geologisch-Paläontologische Mitteilungen Innsbruck, 1: $1-76$.

Crasquin-Soleau, S. \& Gradinaru, E. 1996. Early Anisian ostracode fauna from the Tulcea Unit (Cimmerian North Dobrogean Orogen, Romania). Annales de Paléontologie, 82(2): 59-116.

Crasquin-Soleau, S, Berra, F. \& Rettori, R. 2000. A Late Triassic Ostracod assemblage from the Quattervals Nappe (Austroalpine, Northern Italy). Rivista Italiana di Paleontologia e Stratigrafia, 106: 181-190.

Crasquin-Soleau, S, Galfetti, T, Bucher, H. \& Brayard, A. 2006. Early Triassic ostracods from Guangxi Province, South China. Rivista Italiana di Paleontologia e Stratigrafia, 112: 55-75.

Crasquin-Soleau, S, Galfetti, T, Bucher, H, Kershaw, S. \& Feng, Q. 2007. Ostracod recovery in the aftermath of the Permian-Triassic crisis: Paleozoic-Mesozoic turnover. Hydrobiologia, 585: 13-27.

Delo, D.M. 1930. Some Upper Carboniferous Ostracoda from the shale basin of Western Texas. Journal of Paleontology, 4: 152-178.

Druckman, Y. 1974. The stratigraphy of the Triassic sequence in southern Israel. Israel Geological Survey Bulletin, 64: 1-92.

Eshet, Y. 1990. Paleozoic-Mesozoic palynology of Israel. I. Palynological aspects of the Permian-Triassic succession in the subsurface of Israel. Israel Geological Survey Bulletin, 81: 1-57.

Gerry, E. 1967. Paleozoic and Triassic ostracoda from outcrops and wells in southern Israel. Joint Paleontological Laboratory of the Israel Institute of Petroleum Report, 1/67: 1-13.

Gerry, E. \& Derin, B. 1981. Late Permian-Late Triassic stratigraphy in Israel and its significance to oil exploration. Israel Geological Society, Symposium: Oil exploration in Israel, Abstracts: 9-11.

Gerry, E. \& Oertli, H.J. 1967. Bisulcocypris? triassica n. sp. (Crust., Ostrac.) from Israel. Bulletin Centre de Recherches de Pau-Société Nationale des Pétroles d'Aquitaine, 1: 375-380.

Gerry, E, Honigstein, A, Rosenfeld, A, Hirsch, F. \& Eshet, Y. 1990. The Carnian salinity crisis: ostracods and palynomorphs as indicators of palaeoenvironment. In: Whatley, R. \& Maybury, C. (Eds), Ostracoda and Global Events. Chapman \& Hall, London, 87-97.

Givot Olam. 1995. Meged-2 - Well Completion Report. Vol. 1: Text; Vol. 2: Appendices. Unpublished - 'open well' report available from the Library of the Geological Survey of Israel, Jerusalem.

Goel, R, Kozur, H. \& Srirvastava, S.S. 1984. Middle Anisian (Pelsonian) Ostracoda from Spiti (Himachal Pradesch). India Geoscience Journal, 5: 53-62.

Goubin, N. 1965. Description et repartition des principaux pollenites permiens, triasiques et jurassiques des sondages du bassin de Morondava (Madagascar). Revue de l'Institut Français du Pétrole, 20: $1415-1461$.

Gramm, M.N. 1995. Ostracodes of the suborder Kirkbyocopina from the Middle Triassic of Southern Primor'ye (Far East). Paleontological Journal, 29: 154-156.

Gründel, J. \& Kozur, H. 1972. Zur Taxonomy der Bythocytheridae und Tricorninidae (Podocopida, Ostracoda). Monatsberichte der deutschen Akadademie der Wissenschaften, 13: 907-937.

Hirsch, F. \& Gerry, E. 1974. Conodont- and ostracode biostratigraphy of the Triassic in Israel. Schriftenreihe der Erdwissenschaftlichen Kommissionen, Österreichische Akademie der Wissenschaften, 2: $107-114$.

Jansonius, J. 1962. The palynology of Permian and Triassic sediments, Peace River area, Western Canada. Palaeontographica B, 110, 35-98.

Kolar-Jurkovsek, T. 1991. Microfauna of Middle and Upper Triassic in Slovenia and its biostratigraphic significance. Geologija, 33: 21-170 [in Slovenian].

Korngreen, D. \& Benjamini, C. 2007. Foraminiferal assemblage-based biostratigraphy and correlation of the Triassic of northern Israel. Israel Journal of Earth-Sciences, 55: 209-235.

Korngreen, D. \& Benjamini, C. 2011. Platform to shelf edge transect, Triassic of northern Israel, North Arabian plate. Sedimentary Geology, 236: 164-184.

Kozur, H. 1968. Neue Ostracoden aus dem Rät und Muschelkalk des Germanischen Binnenbeckens. Monatsberichte der deutschen Akadademie der Wissenschaften, 10: 498-519.

Kozur, H. 1973a. Die Bedeutung triassischer Ostracoden für stratigraphische und paläoökologische Untersuchungen. Mitteilungen der Gesellschaft der Geologie- und Bergbaustudenten in Österreich, 21: 632-660.

Kozur, H. 1973b. Einige Bemerkungen zur Systematik der Ostracoden und Beschreibung neuer Platicopida aus der Trias Ungarns und der Slowakei. Geologisch-Paläontologische Mitteilungen Innsbruck, 2: $1-27$.

Kozur, H. 1985. Neue Ostracoden - Arten aus dem Oberen Mittelkarbon (Hoeheres Moskovian), Mittel- und Oberperm des Bükk- Gebirges (N- Ungarn). Geologisch-Paläontologische Mitteilungen Innsbruck, 2: 1-145.

Kozur, H. \& Nicklas, L. 1970. Ostrakoden aus dem Plattenkalk-Niveau des Hauptdolomites (Rhätikon). Festband des Geologischen Instituts, 300-Jahr-Feier Universität Innsbruck, 309-320.

Kozur, H, Kampschuur, W, Mulder-Banken, C.W.H. \& Simon, O.J. 1974. Contribution to the Triassic ostracode faunas of the Betic zone (Southern Spain). Scripta Geologica, 23: 1-56.

Kristan-Tollmann, E. 1983. Ostracoden aus dem Oberanis von Leidapo bei Guiyang in Südchina. Schriftenreihe der Erdwissenschaftlichen Kommissionen, Österreichische Akademie der Wissenschaften, 5: 121-176.

Kristan-Tollmann, E. \& Hamedani, A. 1973. Eine spezifische Mikrofaunen - Vergesellschaftung aus den Opponitzer Schichten des Oberkarn der niederösterreichischen Kalkvoralpen. Neues Jahrbuch für Geologie und Paläontologie, Monatshefte, 143: 193-222.

Kristan-Tollmann, E, Tollmann, A. \& Hamedani, A. 1980. Beiträge zur Kenntnis der Trias von Persien; II. Zur Rhätfauna von Bagerabad bei Isfahan (Korallen, Ostracoden). Mitteilungen der österreichischen geologischen Gesellschaft, 73: 163-235.

Leschik, G. 1956. Sporen aus dem Salzton des Zechstein von Neuhof (bei Fulda). Palaeontographica B, 100: 122-142.

Mandelstam, N.I, Schneider, G.F, Kuznetsova, Z.V. \& Kats, F.I. 1957. [New genera of Ostracoda in the families Cypridae and Cytheridae]. 
Vses. Palentologiche-skogo Obshchestva Ezhegodnik 16: 182-183 [in Russian].

McCoy, F. 1844. A Synopsis of the Characters of the Carboniferous Limestone Fossils of Ireland. Dublin University Press, Dublin, 207pp.

Monostori, M. 1994. Ostracod evidence of the Carnian salinity crisis in the Balaton Highland, Hungary. Neues Jahrbuch für Geologie und Paläontologie, Monatshefte, 193: 311-331.

Pantic, S. 1965. Pilammina densa n. gen., n. sp. and other Ammodiscidae from the Middle Triassic in the Crmnica (Montenegro). Geoloski Vjesnik, Zagreb, 18: 191-193.

Sars, G.O. 1866. Oversigt af marine Ostracoder. Forhandliger $i$ Videnskab-Selskabet Christiana, 8(1865): 1-130.

Sohn, I.G. 1960. Paleozoic species of Bairdia and related genera. US Geological Survey Professional Paper, 330-A, 105pp.
Sohn, I.G. 1968. Triassic Ostracodes from Makhtesh Ramon, Israel. Geological Survey of Israel Bulletin, 44: 1-71.

Sohn, I.G. 1970. Early Triassic Marine Ostracodes from the Salt Range and Surghar range, West Pakistan. In: Kummel, B. \& Teichert, C. (Eds), Stratigraphic Boundary Problems: Permian and Triassic of West Pakistan. Department of Geology, University of Kansas, Special Publication, Lawrence, 4: 149-206.

Urlichs, M. 1972. Ostracoden aus den Kössener Schichten und ihre Abhängigkeit von der Ökologie. Mitteilungen der Gesellschaft der Geologie- und Bergbaustudenten in Österreich, 21: 661-710.

Will, H.J. 1969. Untersuchungen zur Stratigraphie und Genese des Oberkeupers in Nordwestdeutschland. Beihefte zum Geologischen Jahrbuch, 54: 1-240. 


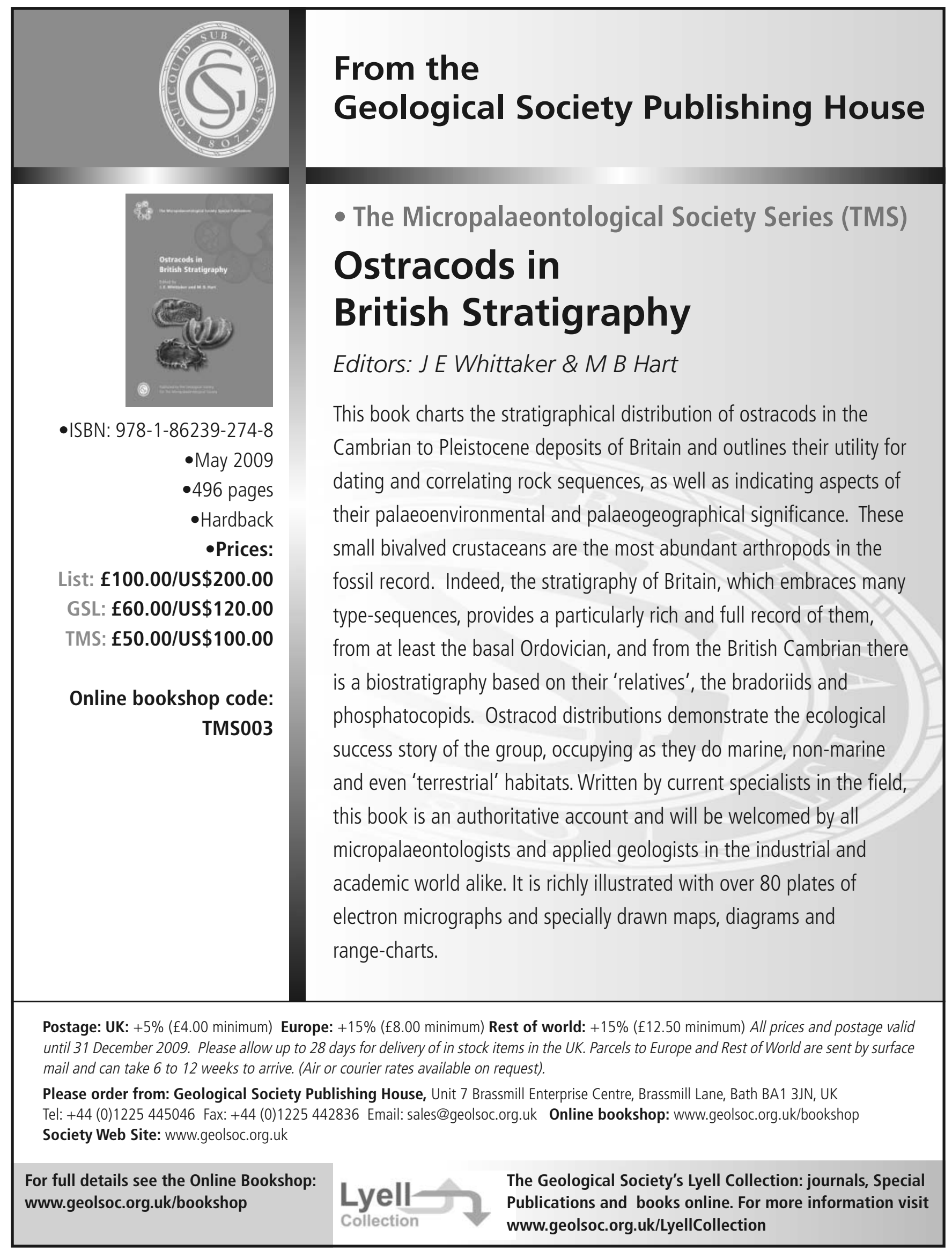

